\title{
Průzkum kontinuálního rmutování *)
}

JOSEF DYR a JOSEF MOS̄TEK za spolupráce diploman tů Miloše Marka a Grigorije N. Chila, Katedra kvasné chemie a technologie VŠCHT v Praze

Kontinuálním způsobưm výroby se už ve všech oborech dostalo náležitého ocenění a není proto třeba zde znovu podrobně rozebírat jejich ekonomické a technologické přednosti. Také do poměrně hodně tradičního sladařství a pivovarství zapustil tento směr vývoje spolehlivě své kořeny. Z dřívějších způsobů jsou dobře známé zejména kontinuální pivovarské kvasné postupy a automatická kontrola iprovozu vypracovaná $M$. W. Couttsem $[1,2$, 3]. O dalších konkrétních formách kontinuálních výrob ve sladařství a pivovarství bylo $\mathrm{v}$ tomto časopise $v$ roce 1959 referováno $F$. Hlaváčkem [4]. Druhým souborným pojednámím o kontinuálních výrobních postupech $\mathrm{v}$ kvasném průmyslu byl zde nedávno publikovaný referát $J$. Dyra [5] z 3. pivovarsko-sladařského semináře, puřadaného ČSVTS v Plzni, konaného dne 9. 12. 1960. V tomto referátu byla také poprvé publikována zmínka o laboratorní aparatuře sestavené na Katedře kvasné chemie a technologie při VŠCHT v Praze podle návrhu J. Dyra.

*) Jde toliko o předběžné sdělení. Podrobná zpráva bude publikována ve Sborníku vŠCHT v Praze, oddilu fakulty potravinářské technologie.
Od té doby se pro omezené technické možnosti v průběhu pokusů ukázala nutnost její určité úpravy. Nyní chceme podat podrobnější charakteristiku této aparatury, zejména po stránce technickotechnologické a uvést některá analytická kritéria rmutů, získávaných sladin, resp. zcukřených rmutů.

Problémy kontinuální přípravy piva vůbec a kontinuální přípravy sladiny zvláště byly intenzívně řešeny zejména $v$ posledním desítiletí. Obdobně jako při periodickém výrobním postupu se vývoj těchto kontinuálních procesů vyhranil do dvou hlavních směrů, a to:

1. Kəntinuální výrobní postupy, založené v podstatě na infuzním rmutování;

2. Kontinuální výrobní postupy, zahrnující technologické prvky dekokčního rmutování.

K první skupině podle dostupné literatury patří zařizení vyvinuté firmou Aluminium Plant Vessel Company [6], výrobní způsob podle Davise a Pollocka [7, 8], sovětský způsob [9] popsaný Malcevem [10] a kanadský způsob popsaný Comptonem a Geigerem [11]. 
K druhé skupině patří především výrobní způsob přihlášený $k$ patentování firmou A. Ziemann [12] v NSR.

Jelikož je pro česká piva charakteristický dekokční rmutovací způsob, bylo naší snahou pojmout tyto technologické prvky i do navrhované aparatury, jejíž funkční schéma je na obr. 1.

\section{Popis aparatury}

Aparatura (obr. 1) se skládá z pěti funkčních nádob, zásobníku šrotu, dvou zásobníků varní vody a sedimentátoru $\mathrm{v}$ podstatě již zcukřeného rmutu (dočasné použití). Vystírková voda $V_{1}$ přitéká nastavenou rychlostí ze zásobníku $Z V_{1}$ do vystírací

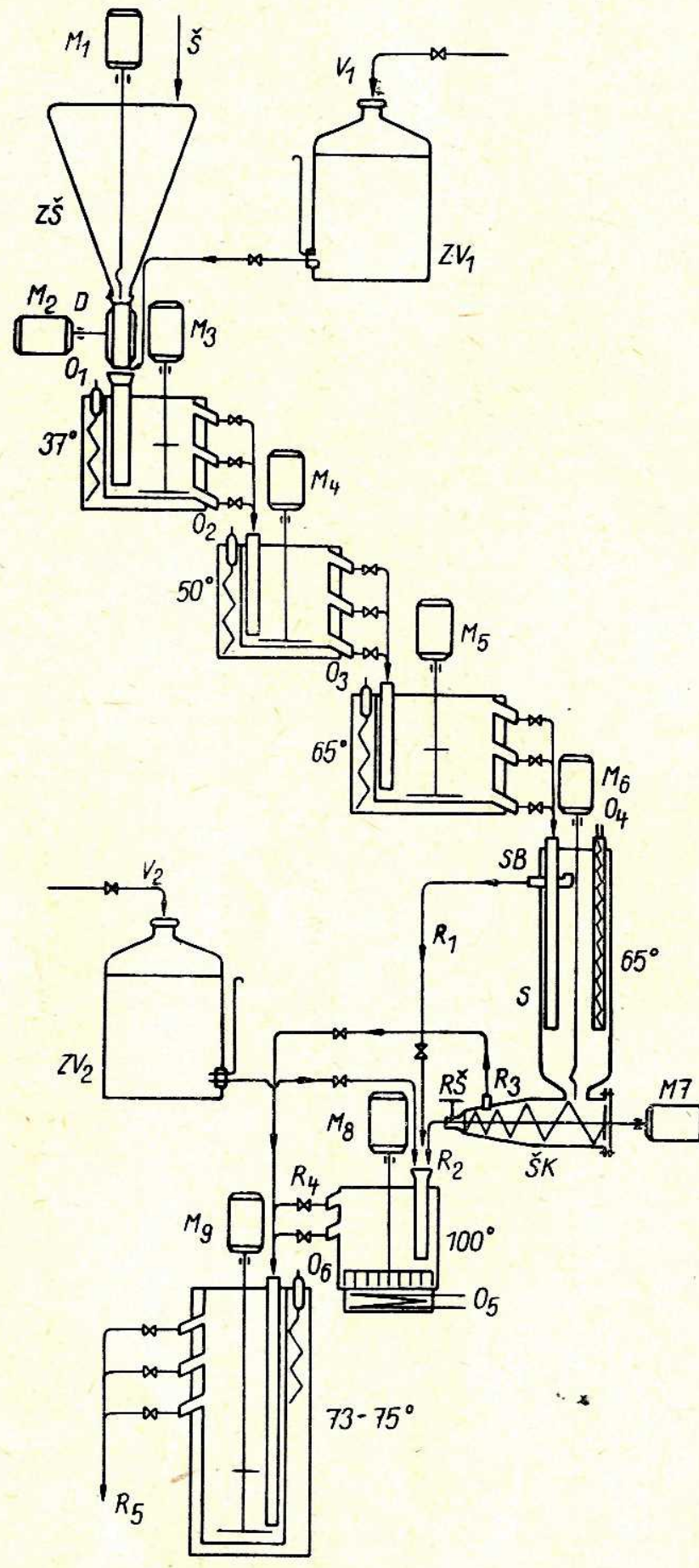

Obr. 1. nádoby, vyhřívané na kyselinotvornou teplotu $37^{\circ} \mathrm{C}$. Zvláštním bubínkovým dávkovačem $D$, poháněným elektromotorkem $M_{2}$ je do této nádoby přiváděn sladový šrot $\breve{S}$ ze zásobníku šrotu $Z \bar{S}$. Kontinuální přítok vody je založen na konstantnim, experimentálně nastaveném hydrostatickém tlaku, při němž daným (cejchovaným) otvorem je průtok prakticky neměnný s chybou menší než $\pm 2 \%$. Při plynulém dávkování šrotu, po napojení hnacího motorku $M_{2}$, přes stabilizátor napětí a vložením čtyřnásobného převodu do pomala mezi motorek $M_{2}$ a hřídelku dávkovače $D$, se rovněž dosáhlo přesnosti lepší než $\pm 2 \%$. Bylo však třeba šrot $v$ kuželovitém zásobníku neustále pomalu míchat zvláštním míchadlem poháněným motorkem $M_{1} \mathrm{~s}$ regulovatelnými otáčkami, aby se nediferencoval co do hrubosti.

Obsahy jednotlivých funkčních nádob, kromě povařovací nádoby, jsou vyhřívány prostřednictvím vodních duplikátorů. Voda v mezistění je vyhřívána ponornými vařiči $O_{1}, O_{2}, O_{3}, O_{6}$ a míchána stlačeným vzduchem. Automatickou regulaci teploty zde přes kontaktní teploměry zajištuje relé. Obsahy jednotlivých nádob jsou míchány hnacími motorky $M_{3}, M_{4}, M_{5}, M_{6}, M_{8}$ a $M_{9}$, u nichž lze regulovat otáčky. Teplota $65{ }^{\circ} \mathrm{C}$ v sedimentátoru $S$ je udržována zvláštním ponorným ohřívačem $O_{4}$ se skleněnou ohřivací plochou. Hustý rmut $v$ povařovací nádobě se přivádí $\mathrm{k}$ varu bud' elektrickým plotýnkovým vařičem, nebo plynovým kruhovým hořákem. Separace hustého podílu rmutu ze dna sedimentátoru $S$ je umožněna podstaveným konickým šnekem $\check{S} K$, poháněným pomaluběžným silnějším motorkem $M_{7}$ se šroubovitým převodem. $\mathrm{V}$ povařovací nádobě je míchadlo hrabičkovitého typu, těsně dosedající na dno, aby se hustý rmut nepřipaloval. Funkční nádoby $37{ }^{\circ} \mathrm{C}, 50{ }^{\circ} \mathrm{C}, 65{ }^{\circ} \mathrm{C}$ a $73{ }^{\circ} \mathrm{C}$ jsou opatřeny třemi odtoky umístěnými $\mathrm{v}$ různých výškách tak, aby bylo možno měnit dobu jednotlivých prodlev, daných rychlostí průtoku nádobou. Vydržováním různě dlouhých prodlev lze regulovat složení sladiny a zpracovávat slady různé kvality. Poměrně velmi malá inaktivace enzymů, hlavně amylolytických, zajištuje nejen dokonalé zcukření, ale slibuje i vyšší varní výtěžky. Přítokové roury jsou pro lepší promíchání vyvedeny, ke dnu jednotlivých nádob. Při dále uváděných pokusech se pra. covalo s těmito účinnými prủtokovými objemy jednotlivých funkčních nádob:

nádoba pro $37{ }^{\circ} \mathrm{C}$ prodlevu . . . . . 2,0 i nádoba pro $50{ }^{\circ} \mathrm{C}$ prodlevu . . . . . 2,01 nádoba pro $65{ }^{\circ} \mathrm{C}$ prodlevu . . . . . 3,6 1 sedimentátor rmutu o $65{ }^{\circ} \mathrm{C}$. . . . . . 4,11 povařovací nádoba $\left(100^{\circ} \mathrm{C}\right)$. . . . 1,81 docukřovací nádoba $73-75^{\circ} \mathrm{C}$. . . . 6,0 1 Tyto objemy jsou dány u použitých válcovitých nádob jejich průměrem a výškou použitého oditoku.

\section{Technologický postup}

Do vystírací nádoby $\left(37{ }^{\circ} \mathrm{C}\right)$ se plynule dávkuje sladový šrot v množství $700 \mathrm{~g}$ /hod a vystírací voda $V_{1}$ v objemu $4900 \mathrm{ml} /$ hod při hustotě vystírky $1: 7$. Objem hodinového průtoku vystírky činí asi 5400 $\mathrm{ml} / \mathrm{hod}$.

Po naplnění vystírací nádoby přechází plynule část díla podle nastaveného průtoku do následujíci nádoby s peptonizační teplotou $50{ }^{\circ} \mathrm{C}$ a po jejím naplnění do další nádoby s cukrotvornou prodlevou $65^{\circ} \mathrm{C}$, resp. její první části. Odtud se v podstatě již zcukřený rmut vede do válcovitého sedimentá- 
toru $S$ temperovaného na stejnou teplotu, tj. $65^{\circ} \mathrm{C}$, který $\mathrm{z}$ hlediska funkčních teplot představuje druhou část cukrotvorné prodlevy. Nejhrubší podíly rmutu $R_{2}$ zde sedimentují ke dnu a jsou konickým šnekem $\widetilde{S} K$ dopravovány do nádoby povařovací. Regulačním šroubem $R \breve{S}$ se může řídit při konstantních otáčkách hnacího motoru $M_{7}$ hustota a podil hustého rmutu. Při špatně rozluštěných sladech nebo při vysoké škrobnaté surogaci se může sběračem $S B$ řídk podíl rmutu $R_{1}$ nad sedimentem odvádět celý, nebo téměř celý do docukřovací nádoby $\left(73\right.$ až $75^{\circ} \mathrm{C}$ ). Výlisky hustého rmutu $\mathrm{z}$ konického šneku se pak ředí $\mathrm{k}$ povařování zatím čistou varní vodou $V_{2}$ ze zásobníku $Z V_{2}$ (při dalším vývoji aparatury se počítá s částí výstřelků). Druhá část řídkého podílu rmutu - rmut $R_{3}$, vzniklá lisováním sedimentu, se vede rovněž do docukřovací nádoby, lze ji však vést podle potřeby dílem i do nádoby povařovací.

Povařený rmut $R_{4}$ přichází ke dnu docukřovací nádoby, kde docukří zmazovatělý podíl škrobu nejhrubších částí šrotu, resp. již mláta enzymaticky ještě bohatým podílem řídkého rmutu. Z této docukřovací nádoby, která funkčně, ve srovnání s dosud $u$ nás užívaným periodickým zpo̊sobem, odpovídá stadiu „odpočinku - scezování předku“, plynule vytéká zcukřený rmut $R_{5}$.

Je naší snahou postưpně vtisknout kontinuální charakter i dalším stadiím přípravy sladiny a mladiny, tj. scezování, vyslazování, chmelovaru, separaci chmele a hořkých kalů, event. ještě chlazení mladiny. Další úseky výroby piva se u nás již řeší zčásti poloprovozně, zčásti provozně.

\section{Analytická část}

Pro posouzení některých analytických kritérí, zejména účinnosti přeměn sacharidických a dusíkatých složek sladu v průběhu tohoto kontinuálnílino rmutování, uvádíme předběžně některé analytické výsledky jednoho z našich pokusů.

Metodika a použitý materiál

Extrakt se stanovil pyknometricky. [13].

Redukujicí látky se stanovily podle Schoorla

Barva se stanovila podle jodových barevných standardů.

Zbytkový extrakt sladiny se stanovil pyknometricky po oddestilování alkoholu při konečném prokvašení [14] za použití kvasnic Smíchov.
Dextriny se stanovily kvasnou metodou podle Srhilda a Weyha [15].

Stupeñ zcukření jednotlivých rmutů je orientačnĕ vypočítán jako procentuální podíl redukujících látek těchto rmutů oproti kongresní sladince po přepočtu na stejnou hustotu.

Dusík se ve všech připadech stanovil kjeldahlizací [14].

Experimentální podmínky stanovení koagulovatelného dusíku byly zvoleny podle Bulgakova [16].

$p H$ se měřilo potenciometricky soustavou elektrod kalomelová - skleněná.

Stanovení celkového extraktu mláta, resp. předsušeného výlisku hustého podílu rmutu se provádělo podle Bulgakova [16]. Obdobně se stanovil rozpustný dusík.

Sacharidické složky se ze vzorků rmutů určených pro chromatografii extrahovaly ethylalkoholem [17].

Byl použit chromatografický papir Whatman č. 4. Použitá chromatografická promývací soustava se skládala z $n$-butanolu: kys. octové : vody $=4: 1: 5$ [obj.].

Detekce se provedla ponořovací technikou acetonovým roztokem benzidinu, kys. trichloroctové a kys. octové $[18,19,20]$.

\section{Přehled a diskuse výsledků}

Sestavená laboratorní aparatura pro kontinuální dekokční rmutování je prvním realizovaným pokusem o řešení tohoto technicko-technologického problému $\mathrm{v}$ ČSSR. V tomto smyslu je také třeba chápat uváděné schéma aparatury a analytické znaky získávané sladiny, resp. zcukřených rmutů. Aparatura a rmutovací pokusy jsou ve stadiu intenzívního zkoumání hlavních technických a technologických parametrů na jedné stranè a chemických a fyzikálně chemických znaků získávané sladiny, resp. zcukřených rmutů, na druhé straně.

Vyhřivání jednotlivých funkčních nádob vodní lázní bylo nutno zvolit proto, že přímé vyhřivání rmutů ponornými elektrickými vařiči ovládanými pomocí relé způsobovalo během delší doby pokusu připékání rmutu na vařič a $v$ pozdější fázi jeho připalování. Účinnost elektrického temperačního zařízení $O_{4} \mathrm{v}$ sedimentátoru $S$ je vhodně snížena přes vestavěný otočný transformátor, aby sedimentace nebyla rušena kinetikou velkého teplotního gradiendu sdíleného tepla. Zde šlo toliko o to, udržet $\mathrm{v}$ sedimentátoru $S$ stejnou teplotu jako

Obsah extraktu a redukujúcích látek rmutủ $v$ jednotlivých funkěních nádobách $v$ závislosti na čase

\begin{tabular}{|c|c|c|c|c|c|c|c|c|c|c|}
\hline \multirow{2}{*}{$\begin{array}{l}\text { Průběžný } \\
\text { čas } \\
\text { v hodinách }\end{array}$} & \multicolumn{2}{|c|}{$37^{\circ} \mathrm{C}$} & \multicolumn{2}{|c|}{$50^{\circ} \mathrm{C}$} & \multicolumn{2}{|c|}{$65^{\circ} \mathrm{C}$} & \multicolumn{2}{|c|}{$65^{\circ} \mathrm{C}$} & \multicolumn{2}{|c|}{$75^{\circ} \mathrm{C}$} \\
\hline & Extrakt & $\begin{array}{c}\text { Redukující } \\
\text { látky }\end{array}$ & Extrakt & $\begin{array}{l}\text { Redukující } \\
\text { látky }\end{array}$ & Extrakt & $\begin{array}{c}\text { Redukující } \\
\text { látky }\end{array}$ & Extrakt & $\begin{array}{l}\text { Redukující } \\
\text { látky }\end{array}$ & Extrakt & $\begin{array}{l}\text { Redukujicí } \\
\text { látky }\end{array}$ \\
\hline $7-13$ & - & - & - & - & - & - & - & - & - & - \\
\hline 14 & - & 1,29 & - & 2,39 & - & 6,88 & - & 7,77 & 11,11 & 8,59 \\
\hline 15 & 2,65 & 1,27 & 3,57 & 2,47 & 8,28 & 6,71 & 10,08 & 7,57 & 11,10 & 8,49 \\
\hline 16 & 2,73 & 1,34 & 3,70 & 2,51 & 8,42 & 6,92 & 9,99 & 7,41 & 11,26 & 8,56 \\
\hline 17 & - & 1,21 & - & 2,34 & - & 6,81 & - & 7,52 & - & 8,61 \\
\hline 18 & 2,72 & 1,38 & 3,59 & 2,41 & 8,33 & 6,78 & 10,00 & 7,49 & 11,23 & $8, \overline{5} 3$ \\
\hline 19 & 2,56 & 1,17 & 3,46 & 2,31 & 8,40 & 6,93 & 10,13 & 7,53 & 11,23 & 8,54 \\
\hline
\end{tabular}




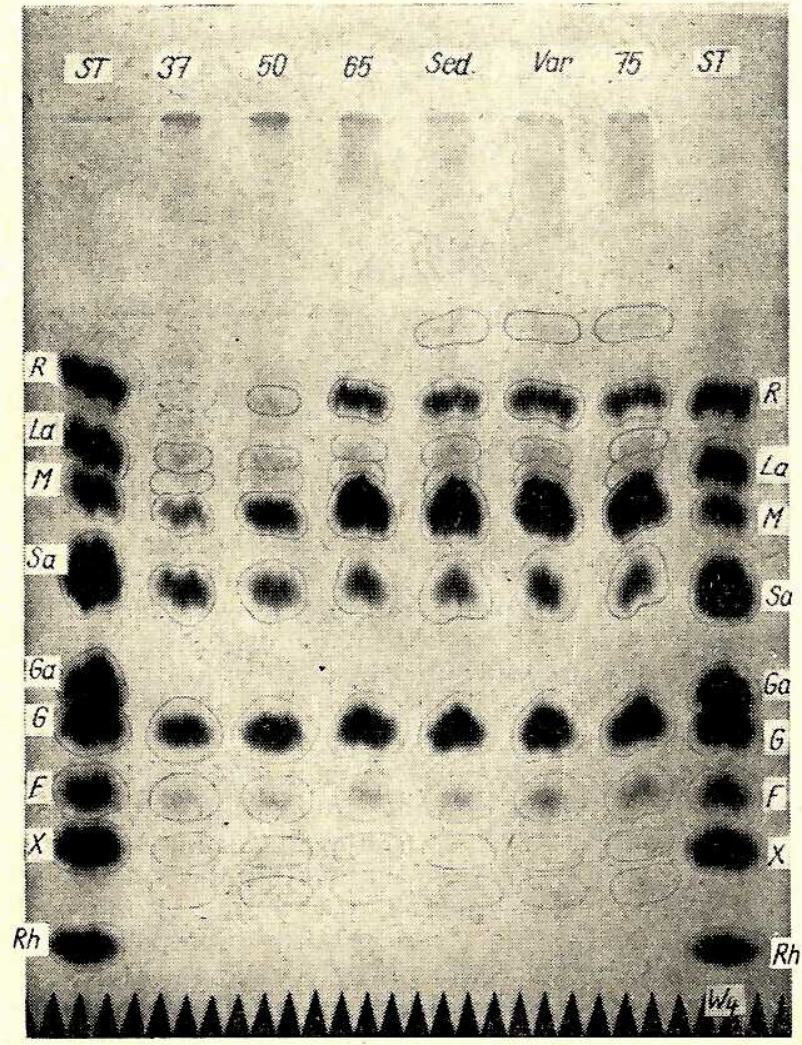

Obr. 2. Chromatografie sacharidů během laboratorního kontinuálnîho dekokčního rmutování

ST - srovnávací standardy čistých cukrủ, R - rafinóza, La laktóza, M - maltóza. Sa - sacharóza, Ga - galaktóza, G - glu(sedimentátor), var (povařovací nádoba), $75^{\circ}$ - vzorky $z$ odpovídajících funkěních nádob

v první části zcukřovací nádoby, tj. $65{ }^{\circ} \mathrm{C}$. Hustý podíl rmutu $R_{2}$, který má obsah vody snížen částečným lisováním v konickém šneku na 55 až $60 \%$ je možno povařovat podle nastavené rychlosti průtoku, event. kvality použivaného sladu či stupně surogace, bud' s částí řídkého rmutu $R_{1}$, event. $R_{3}$, nebo $s$ vodou $V_{2}$.

K povařování hustého podílu rmutu bylo třeba výkonného elektrického plotýnkového vařiče $O_{5}$. Smísením řídkých podílů rmutů $R_{1}$ a $R_{3}$ o teplotě $65{ }^{0} \mathrm{C} s$ povařeným podílem $R_{2}$, resp. již $R_{4}$ se pro nedokonalou tepelnou izolaci aparatury nedosahovalo potřebné dextrinotvorné teploty, proto i tato docukřovací nádoba byla přes relé napojena na ohřivač $O_{6} . \mathrm{K}$ dokonalému zcukření stačila v docukřovací nádobě ta nejmenší nastavitelná prodleva, tj. odvod zcukřeného rmutu $R_{5}$ prvním dolním odvodem.

$\mathrm{Z}$ hodnot tab. 1 je patrno, že uvedeným, $\mathrm{v}$ principu jednoduchým dávkovacím zařízením se dosahovalo velmi dobré vyrovnanosti jak získávaného extraktu, tak i obsahu redukujících látek. Maximální odchylka od průměrné hodnoty byla $\mathrm{v}$ obou případech menší než $1 \%$ a maximální odchylka dvou extrémně rozdílných hodnot byla rovněž $\mathrm{v}$ obou př́ípadech menší než $\pm 2 \%$.

Kvalitativní a relativně kvantitativní zastoupení jednotlivých sacharidických složek rmutů laboratorního kontinuálního rmutování je patrno z obr. 2 . Z tohoto chromatogramu je zřejmý plynulý růst obsahu maltózy a glukózy od stadia vystírky až po hotový zcukřený rmut. Obsah sacharózy zaznamenává mírný pokles, s nímž koresponduje mírně vzrůstající obsah fruktózy. Obsah maltotriózy (při-
Tabulka 2 Zbytkový skutečný extrakt, dosažitelný stupeñ skutečného prokvašení a dextriny konečných sladin $v$ závislosti na čase

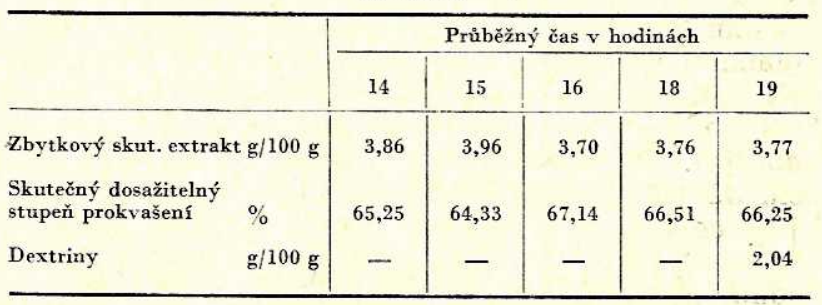

bližně na úrovni $R_{f}$ pro rafinózu] je od stadia $65{ }^{\circ} \mathrm{C}$ až do konce rmutování pra'kticky stejný. Od tohoto stadia je také již zřejmý obsah maltotetraózy (první nad $R$ ) a vzrůstající obsah zřetelně diferencovaných vyšších oligosacharidů a dextrinů.

Pro porovnání účinnosti amylolytického systému sladu při kontinuálním laboratormím rmutovạ́ní oproti provozním podmínkám uvádíme chromatogram (obr. 3) sacharidických složek z běžného provozního periodického dvourmutového dekokčního způsobu. Porovnáním kvalitativního zastoupení jednotlivých sacharidických složek nenacházíme zřetelnějšího rozdílu a rovněž relativně kvantitativní zastoupení těchto složek vzájemně koresponduje s obr. 2.

Z tab. 2 lze vyvodit, že stupeň skutečného dosažitelného prokvašení získávaných sladin (po zfiltrování zcukřených rmutů] kvasnicemi Smíchov je oproti běžným provozním hodnotám o 2 až $4 \%$ vyšší. Tento příznivý jev lze vysvětlit delšími prodlevami při $65{ }^{\circ} \mathrm{C}$, což je vlastně součet prodlev první zcukřující nádoby $\left(65^{\circ} \mathrm{C}\right)$, resp. její první

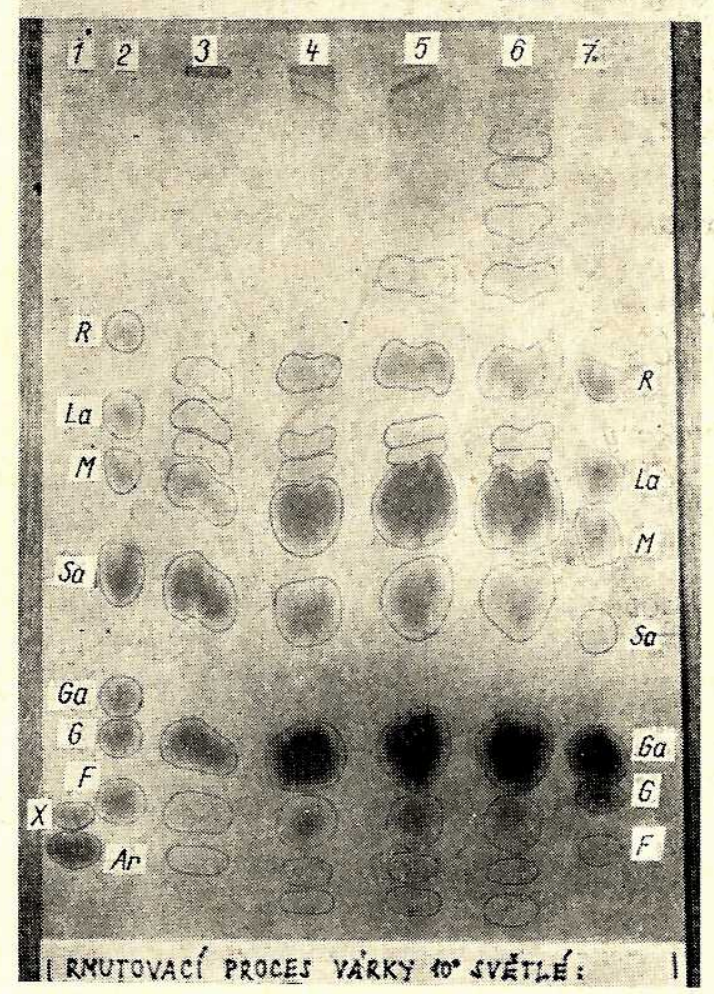

Obr. 3. Chromatografie sacharidů $v$ průběhu dvourmutového provozního periodického varního postupu

1,2 a 7 - srovnávací standardy čistých cukrů, označení cukrú jako obr. $2 ; 3-$ vystírka $\left(37^{\circ} \mathrm{C}\right) ; 4-$ po zapářce $\left[50^{\circ} \mathrm{C}\right) ; 5-1$. rmut
po vyšši cukrotvorné prodlevě $\left(73^{\circ} \mathrm{C}\right) ; 6-$ predek $\left(73-75^{\circ} \mathrm{C}\right)$ 
Analýza výlisku hustého podílu rmutu ze sedimentátoru

\begin{tabular}{|c|c|c|c|c|c|}
\hline \multirow{2}{*}{$\begin{array}{l}\text { Prủběžný čas } \\
\text { odběru vzorku }\end{array}$} & \multirow{2}{*}{$\begin{array}{l}\text { Vláha } \\
\%\end{array}$} & \multirow{2}{*}{$\begin{array}{l}\text { Celkový extrakt } \\
\text { v sušině } \\
\% \text { vah }\end{array}$} & \multirow{2}{*}{$\begin{array}{l}\text { Rozpustný dusík } \\
\text { v sušinè } \\
\mathrm{mg} / 100 \mathrm{~g}\end{array}$} & \multicolumn{2}{|c|}{ Celkový dusík v sušině } \\
\hline & & & & $\%$ dusíku & $\%$ bílkovin \\
\hline 15 & 58,10 & 13,56 & 14,07 & 2,54 & 15,88 \\
\hline 18 & 57,18 & 13,25 & 16,55 & 2,43 & 15,19 \\
\hline
\end{tabular}

části a sedimentátoru a větším šetřením amylolytického enzymového systému sladu dokonalou separací hustého podílu rmutu; oproti provozním podmínkám se povařuje také menší objem větší hustoty $\mathrm{z}$ celkového objemu rmutu. Za těchto podmínek je tedy až do stadia scezování uchována enzymatická aktivita rmutů.

Srovnáme-li po matematické úpravě jednotlivých hustot procentuální obsah redukujících látek sladiny $\mathrm{z}$ konečného zcukřeného rmutu a kongresní

Tabulka 3

Stupeñ zcukrení jednotlivých rmutů oproti kongresní sladinẽ $v$ závislosti na čase* ${ }^{*}$

\begin{tabular}{c|c|c|c|c|c}
\hline $\begin{array}{c}\text { Průběžný cas } \\
\text { v hodinách }\end{array}$ & $37^{\circ} \mathrm{C}$ & $50^{\circ} \mathrm{C}$ & $65^{\circ} \mathrm{C}$ & $65^{\circ} \mathrm{C}$ & $75^{\circ} \mathrm{C}$ \\
\cline { 2 - 6 } 14 & - & - & - & - & 105,6 \\
15 & 15,6 & 30,4 & 82,6 & 93,3 & 104,6 \\
16 & 16,3 & 30,5 & 84,0 & 90,0 & 104,0 \\
18 & 16,8 & 29,3 & 82,5 & 91,2 & 103,9 \\
19 & 14,2 & 28,1 & 84,4 & 91,7 & 103,9 \\
\hline
\end{tabular}

Tabulka 4

Množství rozpustného dusíku $v$ jednotlivých rmutech a jeho porovnání s množstvím rozpustného dusikku kongresní sladiny* ${ }^{*}$

\begin{tabular}{r|c|c|c|c|c}
\hline & $37{ }^{\circ} \mathrm{C}$ & $50{ }^{\circ} \mathrm{C}$ & $65{ }^{\circ} \mathrm{C}$ & $65{ }^{\circ} \mathrm{C}$ & $75{ }^{\circ} \mathrm{C}$ \\
\hline $\begin{array}{r}\text { Množství rozpustného dusíku } \\
\text { mg/100 ml }\end{array}$ & 78,8 & 81,9 & 90,0 & 94,4 & 104,8 \\
$\begin{array}{r}\text { Stupeň rozpustnosti dusíku } \\
\text { oproti kongresní sladině \% }\end{array}$ & 80,2 & 85,1 & 93,6 & 98,1 & 109,0 \\
\hline
\end{tabular}

Analýzy se vztahují na prủběžný čas 19 hod.

*j Jde pouze o první orientačni srovnání.

Tabulka 5

Lundinovy dusikaté frakce a koagulovatelné dusíkaté látky konečné sladiny $z$ průběžného casu 19 hod

\begin{tabular}{|c|c|c|c|c|c|c|c|}
\hline \multicolumn{6}{|c|}{ Lundinovy dusíkaté frakce } & \multirow{2}{*}{\multicolumn{2}{|c|}{$\begin{array}{c}\text { Koagulovatelný } \\
\text { dusík }\end{array}$}} \\
\hline \multicolumn{2}{|c|}{ A } & \multicolumn{2}{|c|}{ B } & \multicolumn{2}{|c|}{ C } & & \\
\hline$\underset{\mathrm{ml}}{\mathrm{mg} / 100}$ & $\begin{array}{c}\% \\
\text { z celk. } N_{2}\end{array}$ & $\underset{\mathrm{ml}}{\mathrm{mg} / 100}$ & $\begin{array}{c}\% \\
\text { z celk. } \mathrm{N}_{2}\end{array}$ & $\underset{\mathrm{ml}}{\mathrm{mg} / 100}$ & $\begin{array}{c}\% \\
\text { z celk. } \mathrm{N}_{2}\end{array}$ & $\underset{\mathrm{ml}}{\mathrm{mg} / 100}$ & $\stackrel{\%}{\%}$ \\
\hline 31,5 & 30,10 & 11,9 & 11,37 & 61,4 & 58,53 & 10,33 & 9,86 \\
\hline
\end{tabular}

Tabulka 6

$p H$ jednotlivých rmutů $v$ závislosti na čase

\begin{tabular}{c|c|c|c|c|c}
\hline $\begin{array}{c}\text { Průběžný čas } \\
\text { v hodinách }\end{array}$ & $37{ }^{\circ} \mathrm{C}$ & $50^{\circ} \mathrm{C}$ & $65^{\circ} \mathrm{C}$ & $65^{\circ} \mathrm{C}$ & $75^{\circ} \mathrm{C}$ \\
\hline & \multicolumn{5}{|c|}{$\mathrm{pH}$} \\
\hline 15 & 5,60 & 5,76 & 5,80 & 5,70 & 5,60 \\
17 & 5,80 & 5,86 & 5,86 & 5,80 & 5,70 \\
19 & 5,78 & 5,74 & 5,74 & 5,70 & 5,60 \\
\hline
\end{tabular}

sladiny téhož sladu, dostáváme o $4 \%$ vyšší stupeň zcukření (tab. 3). Význam tohoto příznivého jevu nelze podceňovat, zvlášt' vezmeme-li znovu v úvahu vysoký stupeň dosažitelného skutečného prokvašení získávaných sladin, i když jsme si vědomi toliko orientačního charakteru tohoto srovnání.

Závěrem diskuse o činnosti amylolytického systému sladu při kontinuálním laboratorním rmutování lze říci, že se podařilo úspěšně nastavit podmínky jeho velmi dobrého působení.

Z tab. 4, 5 a 7 plynou poměry proteolýzy laboratorního kontinuálního rmutování. Celkový obsah dusíku sladiny $\mathrm{z}$ konečného zcukřeného rmutu se pohybuje v mezích hodnot provozního rmutování. Rovněž absolutní a procentuální obsah Lundinových bílkovinných frakcí a koagulovatelného dusíku se nevymyká z těchto mezí. Porovnáním s kongresní sladinkou dostáváme i zde vyšší hodnoty. Lze tedy soudit, že danou aparaturou byly nastaveny vhodně i poidmínky proteolýzy při rmutování, charakteristické pro dekokční způsob.

Hodnoty $\mathrm{pH}$ jednotlivých rmutũ $\mathrm{v}$ závislosti na čase jsou zachyceny $\mathrm{v} t a b$. 6 . Ani tyto hodnoty se nevymykají $z$ běžných mezí provozních rmutů.

\section{Závèr}

Byla sestavena laboratorní aparatura pro kontinuální rmutování (až do stadia scezování), v níž jsou pojaty všechny hlavní technologické prvky periodického dekokčního rmutování charakteristického pro výrobu piv českého typu. Kapacita aparatury je asi 4 litry zcukřeného rmutu za hodinu, o poměru vystírky šrot : voda $=1: 7$ [vah], poskytující „předek“ o hustotě 11 až $12 \%$ vah. Podle obsahu redu'kujících látek a chromatografického porovnání jednotlivých sacharidických složek se sladina zcukřených rmutů z dané aparatury $\mathrm{v}$ podstatě neliší od provozních předků, ve stupni konečného skutečného prokvašení se jeví naopak o 2 až $4 \%$ zkvasitelnější. Dusíkaté poměry a hodnoty pH jednotlivých rmutů se rovněž nevymykají z mezí hodnot provoznich dekokčních rmutů.

\section{Literatura}

[1] USA patent č. 27775522.

[3] Mitt. V. Gärungsgewerbe 14,103 (1960); ref. Kvas. prüm. 7, 93 (1951)

$$
\text { (1951). }
$$

[4] Schultze-Berndt Hans G.: Die Brauerei 13, 308 [1959].

[5] Dyr J.: Kvasný prủmysl 7,25 (1961)

[5] Myr J.: Kvasný prủmysl 7, 25 (1961).

[7] Davis J., Pollock I. R. A.: J. Inst. Brewing, 65, 15 (1959).
[8] Britský patent č. 810146.

[S] SSSR patent č. 617932 .

10] Malcev P. M.: Technologija brodilnych proizvodstv, Moskva 1960.

11] USA patent $\check{c} .2,894841$.

13] Jureček M.: Organická analysa II, Praha 1957.

14] de Clerck Jean, Lehrbuch der Brauerei, Bd. II, Berlin 1952.

151 Schild E., Weyh H.: Brauwissenschaft 11,198 (1958).

[16] Bulgakov N.: Proizvodstvennyj i laboratornyj kontrol solodoraščenija i pivovarenija, Moskva 1959.

[17] Hais I. M., Macek K.: Papírová chromatografie, Praha 1959.

[18] Harris G., MacWilliam I. C., ref. Sugar. Ind. Abstr. 16, 85 [1954].

[19] Dyr J. a Moštek J.: Kvasný průmysl 4, 121 [1958).

[20] Dyr J. a Moštek J.: Kvasný prủmysł 4, 169 (1958).

[21] Pinkava J.: Laboratorni technika kontinuálnich procesủ, NČSAV, Praha 1958

Došlo do redakce 28. 6. 1961. 
ИССЛЕДОВАНИЕ НЕПРЕРЫВНОГО МЕТОДА ЗАТИРАНИЯ

В статье описывается лабораторная установка созданная для изучения технологии непрерывного затирания Stadium der Abläuterung) zusammen(вплоть до фильтрации затора) gestellt, welche die Einhaltung aller включающей все типичные элементы wichtiger technologischer Elemente декокционного метода затирания, ха- des für die Herstellung böhmischer рактерного для производства чеш- Biere charakteristischen periodischen ского пива. Результаты анализов по- Dekoktionsmaischens ermöglicht. Die казывают, что сладкое сусло при Analysenergebnisse zeigten, dass zwiнепрерывнюм затирании не отлича- schen der Laborwürze und den im Deется по существу от сусла получае- koktionsverfahren hergestellten Beмого при декокционном затирании. triebswürzen keine wesentlichen Фактическая степень сбраживания Unterschiede bestehen. Der erzielte при непрерывном методе повышается wirkliche Vergärungsgrad war sogar о $4 \%$. Кислотные числа проверочных um 4\% höher. Auch die Stickstoffverварок и содержание в них азотистых hältnisse und die pH-Werte beweсоединений не выходят за пределы gen sich innerhalb der Grenzwerte, значений обычных у сусла получен- die bei Betriebs-Dekoktionsmaischen ного отваркой.

\section{TESTING CONTINUOUS MASHING}

The article deals with a laboratory equipment designed and built for studying the technology of continuous mashing (up to the straining stage) comprising all the technologic elements of conventional method i. e. of decoction process characteristic for Czech beer. The results of analyses indicate that the wort does not differ from wort obtained by decoction. The fermentation limit is in continuous process by $4 \%$ higher. Acid numbers and nitrogen compounds content of several experimental brews do not exceed the limits typical for decoction process. 